\title{
COMPARISON OF LENGTH OF STAY AND DEEP VEIN THROMBOSIS (DVT) INCIDENTS IN DR. SOETOMO HOSPITAL
}

\author{
Elizeus Hanindito ${ }^{1}$, Prananda Surya Airlangga ${ }^{1}$, Soni Sunarso Sulistiawan ${ }^{1}$, Bambang Pujo Semedi ${ }^{1}$, Lucky \\ Andriyanto $^{1}$, Arie Utariani ${ }^{1}$, Nancy Margarita Rehatta ${ }^{2}$ \\ ${ }^{1}$ Department of Anesthesiology and Reanimation, ${ }^{2}$ Professor of Anesthesiologist and Reanimation, Department of \\ Anesthesiology and Reanimation, Faculty of Medicine, Universitas Airlangga, Dr. Soetomo Hospital, Surabaya, \\ Indonesia
}

\section{ABSTRACT}

Vein thrombosis may occur both in deep and superficial vein of all extremities. Ninety percent of vein thrombosis may progress into pulmonary embolism which is lethal. Deep vein thrombosis (DVT) is frequently found in critically ill patients in ICU, especially patients who are treated for a long time. This study aims to analyse the comparison between length of stay and DVT incidents in critically ill patients. A cross-sectional study was employed. We include all patients who were 18 years or older and were treated in ICU of Dr Soetomo public hospital for at least 7 days. The patients were examined with Sonosite USG to look for any thrombosis in iliac, femoral, popliteal, and tibial veins and Well's criteria were also taken. This study showed that length of stay is not the only risk factor for DVT in patients treated in ICU. In our data, we found out that the length of treatment did not significantly cause DVT. Other risk factors such as age and comorbidities in patients who are risk factors may support the incidence of DVT events. The diagnosis of DVT is enforced using an ultrasound performed by an expert in the use of ultrasound to locate thrombus in a vein. Length of treatment is not a significant risk factor for DVT. Several other factors still need to be investigated in order for DVT events to be detected early and prevented.

Keywords: Deep vein thrombosis (DVT); Intensive Care Unit (ICU); length of stay

\section{ABSTRAK}

Pembuluh darah vena dapat terjadi baik di vena dalam dan superfisial dari semua ekstremitas. Sembilan puluh persen dari trombosis vena dapat berkembang menjadi emboli pulmonal yang mematikan. Trombosis vena dalam (DVT) sering ditemukan pada pasien sakit kritis di ICU, terutama pasien yang dirawat untuk waktu yang lama. Penelitian ini bertujuan untuk menganalisis perbandingan antara lama tinggal dan insiden DVT pada pasien sakit kritis. Sebuah studi cross-sectional digunakan. Kami termasuk semua pasien yang berusia 18 tahun atau lebih dan dirawat di ICU rumah sakit umum Dr Soetomo selama setidaknya 7 hari. Para pasien diperiksa dengan USG Sonosite untuk mencari setiap trombosis di vena iliaka, femoralis, poplitea, dan tibia dan kriteria Well juga diambil. Penelitian ini menunjukkan bahwa lama tinggal bukan satu-satunya faktor risiko DVT pada pasien yang dirawat di ICU. Dalam data kami, kami menemukan bahwa lama pengobatan tidak menyebabkan DVT secara bermakna. Faktor risiko lain seperti usia dan komorbiditas pada pasien yang merupakan faktor risiko dapat mendukung kejadian kejadian DVT. Diagnosis DVT ditegakkan menggunakan ultrasound yang dilakukan oleh seorang ahli dalam penggunaan USG untuk menemukan thrombus di pembuluh darah. Lama pengobatan bukan faktor risiko yang signifikan untuk DVT. Beberapa faktor lain masih perlu diselidiki agar kejadian DVT terdeteksi dini dan dicegah.

Kata kunci: Deep vein thrombosis (DVT); Intensive Care Unit (ICU); lama rawat inap

Correspondence: Elizeus Hanindito, Department of Anesthesiology and Reanimation, Faculty of Medicine Universitas Airlangga, RSUD Dr. Soetomo, Jl. Mayjen Prof Dr. Moestopo 47 Surabaya, Indonesia. Phones: (031)5501835, (031)5501504, 0811334332, 08155065323. E-mail: kppmanestesi.unair@gmail.com

pISSN:2355-8393 • eISSN: 2599-056x • doi: http://dx.doi.org/10.20473/fmi.v54i3.10004

- Fol Med Indones. 2018;54:278-281 • Received 28 Aug $2017 \bullet$ Accepted 1 Feb 2018

- Open access under CC-BY-NC-SA license • Available at https://e-journal.unair.ac.id/FMI/

\section{INTRODUCTION}

Venous thrombosis can occur in both deep and superficial veins in all four extremities. In $90 \%$ of cases, deep venous thrombosis may develop into pulmonary embolism, and in high-risk conditions can cause death (Kaushansky et al 2010). 
The incidence of venous thrombosis is approximately 1 per population per year. In one-third cases manifest as pulmonary embolism, whereas two-thirds are limited to DVT. The mortality rate in DVT cases is $6 \%$ in cases of pulmonary embolism as 1 month of DVT diagnosis and pulmonary embolism is established (Cushman 2007). In one study, it was found that the mortality rate from pulmonary embolism was $30 \%$, including cases of pulmonary embolism diagnosed from the autopsy (White, 2014) The formation, enlargement and reshuffle of venous thromboembolism depends on the balance between thrombogenic stimulation and protective mechanism (thrombolytics).

In 1859, Rudolph Virchow concluded that thrombogenic stimulation factors are blood flow stasis, changes in blood vessel walls, and hypercoagulability. The mechanisms of thrombotic thrombus-induced thrombogenic stimulation, particularly those related to damage to blood vessel walls, can be clearly illustrated in arterial thrombosis, but in the vein, the mechanism remains unclear. For example, in the Sevitt study, there was no evidence of damage to the vein wall in 49 of 50 cases. It becomes interesting to discussed in this paper to explain the mechanism of venous thrombosis, especially in intact veins (Lopez et al 2004)

Clinical manifestations of venous thrombosis include leg pain, tenderness, swelling, discoloration, venous distention, superficial venous projection, and cyanosis (Fauci et al 2008, Hirsh et al 1996, Kerr at al 1990). However, clinical DVT diagnosis is not specific because each of the symptoms above can be caused by nontrombotic abnormalities (Kerr et al, 1990). Even in some cases, DVT can occur without symptoms, until it eventually develops into pulmonary embolism and causes sudden death (Hirsh et al 1986, Kerr et al 1990). The unusual clinical symptoms of DVT and its complications that lead to death can even suddenly occur, making DVT an interesting and important case for discussion, so it can be accurately diagnosed (Fauci et al 2008, Hirsh et al 1986, Kerr at al 1990).

Length of Stay (LOS) is one indicator of hospital service to measure the efficiency of hospital service. Prolonged hospitalization not only increases maintenance costs and reduces hospital service efficiency but also deals with other complications such as nosocomial infections, immobility, decubitus and Deep Vein Thrombosis (DVT), which worsen the quality of life of patients (Kerr et al, 1990). Therefore, the objectives of this study was to examine the association between time of hospitalization and the incidence of Deep Vein Thrombosis (DVT) in patients with long hospitalization

\section{MATERIALS AND METHODS}

A cross-sectional study was employed in ICU of Dr. Soetomo public hospital. The study population included all hospitalized patients who were 18 years or older and were treated in ICU of Dr. Soetomo public hospital for at least 7 days. Patients were included if they had a long bed-rest and with a minimal activities in ICU because of disease and treatment. The study was designed to enroll a sample of at least 31 patients, which was considered enough to estimate the true proportion of positive patients who got deep vein thrombosis in long hospitalized in ICU of Dr. Soetomo.

\section{Data Collection}

Data were collected on spesific period of time from June 2016 until June 2017 and took patients for samples without any specific diagnosis and treatment were given to the patients, in conditions which the patients can be examined by intensivist in ICU for looking the possibility found the deep vein thrombosis in lower extremities with a big vein anastomose, if there were any wounds, unstable conscious, and minimalized movements it cannot be examined. So the intensivist would looking for in the safe area until found any deep vein thrombosis in enough time, so the patients did not disturbed until feel any pain or agited.

\section{Ultrasound examination}

The examination was performed by a certified intensivist. The Sonosite USG used to look for any thrombosis in illiac, femoral, popliteal, and tibial veins. If signs of thrombi in any size were considered positive.

\section{RESULTS}

The totally subjects were 31 patients enrolled, 19 patients with thrombus and 12 patients without thrombus. This study aims to analyse the comparison between length of stay and DVT incidents in critically ill patients.

Table 1. Population Data based on Age

\begin{tabular}{lccccc}
\hline \multirow{2}{*}{ Age } & \multicolumn{2}{c}{ Thrombus } & \multirow{2}{*}{ Total } & P \\
\cline { 2 - 3 } & \multicolumn{2}{c}{ Yes $(\%)$} & No $(\%)$ & & \\
\hline <15 years & $0(0 \%)$ & $1(100 \%)$ & 1 & \\
16-25 years & $2(50 \%)$ & $2(50 \%)$ & 4 & \\
26-40 years & $1(33.3 \%)$ & $2(66.7 \%)$ & 3 & \\
41-55 years & $13(72.2 \%)$ & $5(27.8 \%)$ & 18 & \\
$>56$ years & $3(60 \%)$ & $2(40 \%)$ & 5 & \\
Total & $19(61.3 \%)$ & $12(38.7 \%)$ & 31 & 0.449 \\
\hline
\end{tabular}


A total of 31 patients were hospitalized on the day of the study in ICU Dr. Soetomo Hospital. Based on Table 1 , the thrombus occurred mostly in a 41-55 years' group of patients $(42 \%, \mathrm{n}=13)$ and less occurred in an under 15 years' group of patients $(0 \%, \mathrm{n}=0)$. But there is no significant difference between categories because $p$ value $=0.449(>0.05)$.

Table 2. Characteristic Data based on Sex

\begin{tabular}{ccccc}
\hline \multirow{2}{*}{ Sex } & \multicolumn{2}{c}{ Thrombus } & \multirow{2}{*}{ Total } & \multirow{2}{*}{$\mathrm{P}$} \\
\cline { 2 - 3 } & Yes $(\%)$ & No $(\%)$ & & \\
\hline Male & $7(41.2 \%)$ & $10(58.8 \%)$ & 17 & \\
Female & $5(35.7 \%)$ & $9(64.3 \%)$ & 14 & \\
Total & $12(38.7 \%)$ & $19(61.3 \%)$ & 31 & 0.525 \\
\hline
\end{tabular}

Based on Table 2, male patients are more often having a thrombus than female patients $(32 \%, \mathrm{n}=10$ vs $29 \%$, $\mathrm{n}=9$ ). But there is no significant difference between male and female patients because $\mathrm{p}$ value $=0.525$ $(>0.05)$.

Table 3. Length of Stay in ICU

\begin{tabular}{ccccc}
\hline \multirow{2}{*}{$\begin{array}{c}\text { Length of } \\
\text { stay }\end{array}$} & \multicolumn{2}{c}{ Thrombus } & \multirow{2}{*}{ Total } & p \\
\cline { 2 - 3 } 1 week & $5(83.3 \%)$ & $1(16.7 \%)$ & 6 & \\
2 week & $5(45.5 \%)$ & $6(54.5 \%)$ & 11 & \\
3 week & $4(57.1 \%)$ & $3(42.9 \%)$ & 7 & \\
4-7 week & $5(71.4 \%)$ & $2(28.6 \%)$ & 7 & \\
Total & $19(61.3)$ & $12(38.7 \%)$ & 31 & 0.433 \\
\hline
\end{tabular}

\section{DISCUSSION}

This study that the length of treatment did not significantly cause DVT. Based on table 3 , there are no significant difference in DVT incidents between each category. But in population data based on age, there are significant differences between each category. DVT commonly occur in 41-55 years' group. This corresponds to one of the risk factors in DVT, which is old age. In this study also found significant differences in categories of data by sex. In Table 2, it was found that DVT was more common in male patients than in female patients.

The results of our research may have important implications for clinical practice. Clinicians may estimate that DVT is susceptible to male patients and/or patients in aged 45-55 years. In addition, clinicians are also expected to be more cautious, as DVT may also occur in bed rest patients less than 1 week, so doctors treating patients in ICU are expected to detect DVT earlier.
This study has several limitations. First, the insignificant differences in length of ICU admissions and DVT events can be attributed to insufficient number of samples. In the calculation of the number of samples, the sample should be 422 patients. So it is necessary to make further research to increase the number of samples. Secondly, the study did not exclude patients receiving anti-coagulant therapy, which may result in false-negative results in long-term beds but received anticoagulant therapy which is often used as DVT prophylaxis. Third, we used USG as a tool to diagnose DVT. Ultrasonography is non-invasive and inexpensive. However, the sensitivity of screening ultrasound for venous thrombosis in asymptomatic patients was found to be poor for both proximal and distal DVT, because it depends on the number of pathological compression maneuvres documented in the ultrasound (Schellong et al 2005).

\section{CONCLUSION}

Length of treatment is not a significant risk factor for DVT. Several other factors still need to be investigated in order for DVT events to be detected early and prevented. Several factors, such as age and sex influence DVT events can influence DVT events in critically ill patient.

\section{REFERENCES}

Cushman, M. 2007. Epidemiology and Risk Factors for Venous Thrombosis. SeminHematol. April ; 44(2): 62

Fauci, AS, DL Kasper, DL Longo, E Braunwald, SL Hauser, JL Jameson, JLoscalzo. 2008. Venous Thrombosis. Dalam: Harrison's Principles of Internal Medicine 17th Edition. Chapter 111. USA: McGrawHill Companies,Inc.7.

Hirsh, J dan J Hoak. 1996. Management of Deep Vein Thrombosis and Pulmonary Embolism Circulation. http://circ.ahajournals.org/content/93/12/2212.full. 5 November 2014, (22.00)

Hirsh, J, RD Hull, dan GE Raskob. 1986. Epidemiology and Pathogenesis of Venous Thrombosis. The J Am Coll Cardio. http://content.onlinejacc.org/data/Journals/JAC/22739/ 00122.pdf. 5 November 2014, (22.00)

Kaushansky, K, MA Lichtman, E Beutler, TJ Kipps, U Seligsohn, JT. Prchal. 2010. Venous Thrombosis. 2700. Williams Hematology, 8th edition. China: TheMcGraw-Hill Companies, Inc. P.

Kerr T.M et al. 1990. Upper Extremity Venous Thrombosis Diagnosed by DuplexScanning, The Am J of Surgery 160:120-206.10 
Lopez, JA, C Kearon, dan AYY Lee. 2004. Deep Venous Thrombosis. Hematology. ASH Education Book January 1: vol. 2004 no. 1 439-4563.

Schellong S, Hesselschwerdt HJ, Paar WD, et al. 2005. Rates of proximal deep vein thrombosis as assessed by compression ultrasonography in patients receiving prolonged thromboprophylaxis with low molecular weight heparin after major orthopedic surgery. Thromb Haemost; 94: 532-6

White, R. 2003. The Epidemiology of Venous Thromboembolism. Circulation. http://circ.ahajournals.org/ content/107/23_suppl_I/I-4. 7 November 2014 (20:00) 